\title{
Management of white mold of soybean using winter cereal straw
}

\section{Leandro André Feller ${ }^{1}$ Jessica Vanessa Wosniak Corrêa ${ }^{1}$ (D) Carla Daiane Leite ${ }^{2}$ Leandro Alvarenga Santos ${ }^{3(\mathbb{D})}$ Cacilda Márcia Duarte Rios Faria ${ }^{1^{*}}$ Marcelo Cruz Mendes $^{1(\mathbb{D})}$}

\author{
${ }^{1}$ Programa de Pós-graduação em Produção Vegetal, Universidade Estadual do Centro Oeste (UNICENTRO), Guarapuava, PR, Brasil. E-mail: \\ criosfaria@hotmail.com.*Corresponding author. \\ ${ }^{2}$ Universidade Tecnológica Federal do Paraná (UTFPR), Pato Branco, PR, Brasil. \\ ${ }^{3}$ Programa de Pós-graduação em Recursos Genéticos Vegetais, Universidade Estadual de Feira de Santana (UEFS), Feira de Santana, BA, Brasil.
}

\begin{abstract}
The management of white mold (Sclerotinia sclerotiorum(Lib.) De Bary) has been one of the main production limitations faced by soybean (Glycine max L.) producers. Considering the complex management of this disease and resistance structure of the pathogen, the present study was conducted in the municipalities of Guarapuava and Palmas in Parana with the objective of managing the white mold of soybean using straws of winter cereals, such as oat, rye, and triticale. Initially, the three winter cereals were cultivated simultaneously in both the study areas. Straw production, plant height, and shoot fresh and dry weight were evaluated. Subsequently, BMX Apollo soybean was cultivated on cereal straws, and the incidence and severity of white mold were evaluated. In the in vitro experiment, 20 sclerotia covered by a layer of cereal (oat, rye, and triticale) straws were added and carpogenic germination was observed only in the control treatment after 98 days. Regardless of the study site, rye presented greater height and fresh weight than the remaining two cereals. Soybean cultivation on winter cereal straw reduced the incidence and severity of white mold. Cultivation on rye straw reduced mold incidence by $77.7 \%$ and $76.6 \%$ in Palmas and Guarapuava, respectively.
\end{abstract}

Key words: Sclerotinia sclerotiorum, Glycine max, straw, No-till, disease management.

Manejo do mofo-branco na cultura da soja pelo uso de cobertura do solo com cereais de inverno

RESUMO: O manejo do mofo branco (Sclerotinia sclerotiorum) tem sido um dos principais limitantes de produção enfrentados por produtores de soja. Tendo em vista a complexidade do manejo desta doença e da estrutura de resistencia do patógeno, o presente trabalho foi conduzido nos municípios de Guarapuava e Palmas - Paraná visando o manejo do mofo branco na cultura da soja utilizando palhadas de cereais de inverno, aveia, centeio e triticale. Inicialmente, cultivou-se os diferentes cereais de inverno, simultaneamente, nas duas áreas de estudo (Guarapuava e Palmas - PR). Avaliou-se a produção de palhada, a altura de plantas, a massa verde e seca da parte aérea. Posteriormente, semeou-se soja 'BMX Apolo' sobre as palhadas de cereais e avaliou-se a incidencia e a severidade do mofo branco. No experimento in vitro, adicionou-se 20 escleródios cobertos por uma camada de palhas (aveia, centeio e triticale) e após 98 dias, observou-se germinação carpogenica somente no tratamento testemunha. Independentemente do local de estudo, o centeio destacou-se com maiores altura e massa verde. O cultivo sobre palhada de cereais de inverno reduziu a incidencia e severidade de mofo branco com destaque para a palhada de centeio, reduzindo a incidencia da doença em 77,7\% e 76,6\%, em Palmas e Guarapuava, respectivamente.

Palavras-chave: Sclerotinias clerotiorum, Glycine max, palhada, plantio direto, manejo de doenças.

\section{INTRODUCTION}

White mold, caused by the fungus Sclerotinia sclerotiorum (Lib.) De Bary, affects approximately 650 plant species, particularly soybean (Glycine max L.). In Brazil, the incidence of soybean white mold has significantly reduced crop production (TUPICHET al., 2017).

High humidity and temperatures between $10{ }^{\circ} \mathrm{C}$ and $21{ }^{\circ} \mathrm{C}$ favor carpogenic germination, which is characterized by the emission of apothecia containing asci and ascospores that are disseminated by the wind for 2 to 3 weeks. The management of soybean white mold generally involves an integrated program of measures including cultural practices, since chemical control alone is inefficient. The use of a physical barrier, derived from conventional crop remains, can affect the carpogenic germination of $S$. sclerotiorum sclerotia, thereby reducing the initial inoculum of the pathogen, in addition to improving chemical, physical, and biological characteristics of soil (VENTUROSO et al., 2013).

The potential use of dead cover in the management of soil-dwelling pathogens has already 
been reported for Rhizoctonia solani, Sclerotium rolfsii, and Pythium spp. in pepper (HANSENA \&KEINATH, 2013) as well as for S. sclerotiorumin soybean (Brachiaria used as dead cover) (GORGEN et al., 2009; 2010). However, few studies have evaluated the effectiveness of straws of winter cereals grown in southern Brazil as dead cover in the management of soybean white mold.

Thus, the objective of this study was to assess the optimum quantity and effectiveness of oat, rye, and triticale straws in the management of soybean white mold in the municipalities of Guarapuava and Palmas, Paraná, Brazil.

\section{MATERIALS AND METHODS}

\section{Production of winter cereal straw}

The experiments were conducted simultaneously in two municipalities of Paraná, Brazil, during the 2013-2014 harvest. The first experimental site is located in the municipality of Guarapuava (25⒉ $6^{\prime} 3.45^{\prime \prime} \mathrm{S}, 51^{\circ} 39^{\prime} 24^{\prime \prime} \mathrm{W} ; 946 \mathrm{~m}$ MSL), andthe second study site is located in the municipality of Palmas (26 27'49.67"S, 51 $50^{\circ} 00.39^{\prime \prime} \mathrm{W} ; 1,247 \mathrm{~m}$ MSL). The climate of the municipalities is type Cfa (humid subtropical climate) according to the KoppenGeiger classification. Mean annual temperature ranges between $16^{\circ} \mathrm{C}$ and $20^{\circ} \mathrm{C}$, and mean rainfall is 1,880 mm per year (CUNHA et al., 2011).

Treatments included soybean cultivation in uncovered soil (control) and in soil covered with straw. The winter cereals used in the treatments were Embrapa 29 Garoa black oat (Avena strigose Schreb.), BRS Serrano rye (Secale cereale L.), and BRS Saturno triticale (X Triticosecale Wittmack.).

The winter cereals were sown using 80 $\mathrm{m}^{-2}$ seeds, with a buffer of $17 \mathrm{~cm}$ between plantation rows. Phytosanitary treatment, soil correction, and fertilization followed the technical recommendations for crops (Mundstock, 1983). The experiment was conducted using a randomized block design, with seven replications, in $3 \mathrm{~m} \times 10 \mathrm{~m}$ plots.

Samples of winter cereals from the central rows were collected manually, and plant height, fresh weight, and dry weight were measured. Dry weight was measured after drying the plants in an oven under forced air circulation at $65^{\circ} \mathrm{C}$ for 72 hours. All measurements were obtained at the $\mathrm{V} 11.1$ vegetative stage, corresponding to the milky grain stage.

To evaluate treatment effects, analysis of joint variance was performed in a factorial arrangement with two sites (Guarapuava and Palmas) and four treatments, with means (winter cereals) compared by the Tukey test at 5\% probability.
In vitro effects of winter cereal straws on the carpogenic germination of Sclerotiniasclerotiorum

Sclerotia were collected from soybean plants showing signs of white mold. These structures were surface sterilized (70\% alcohol and 1\% sodium hypochlorite for 60 seconds) and cultivated on a ricebased substrate to obtain the inoculum. The sclerotia produced on rice were selected according to size (2-3 $\mathrm{cm}$ ) for further experiments.

The inhibition of carpogenic germination of $S$. sclerotiorum using straws of different winter cereals was evaluated on the basis of two factors; the first factor was based on high productivity reported in the literature, resulting in a yield of 10 $\mathrm{t} \cdot \mathrm{ha}^{-1}$ (Meinerz et al., 2011), and the second factor was the actual yield obtained in field experiments (Guarapuava and Palmas).

The experimentswere conducted in Gerbox plastic boxes containing the AA culture medium (water agar, $20 \mathrm{~g} \cdot \mathrm{L}^{-1}$ ), on which 20 pre-sterilized sclerotia were inoculated. Subsequently, soil (4 mm layer) and cereal straws were placed carefully. The boxes were placed in a BOD incubator at $20^{\circ} \mathrm{C}$ under a 12-hour photoperiod for 98 days. Evaluations were performed weekly by quantifying the formation of apothecia resulting from the carpogenic germination of sclerotia. The experiment followed a completely randomized design, with five replications of 20 sclerotia per box.

\section{Effects of winter cereal straws in the management of soybean white mold under field conditions}

The areas cultivated with winter cereals were desiccated $\left(3.0 \mathrm{~L} \cdot \mathrm{ha}^{-1}\right.$ glyphosate) for sowing BMX Apollo soybean. Pre-sowing fertilization was performed using $100 \mathrm{~kg} \cdot \mathrm{ha}^{-1}$ potassium chloride, and $200 \mathrm{~kg} \cdot \mathrm{ha}^{-1} 8-20-18 \mathrm{NPK}$ was added to plantation rows. The spacing between the rows was $50 \mathrm{~cm}$, and the linear sowing density was 10 seeds per meter. From the R2 stage (full flowering) of soybean, the incidence of white mold was evaluated onthe middlethird of the main stem, according to the methodology described by Guareschi et al. (2012). Disease severity was assessed based on a scale proposed by Juliatti et al. (2013). White mold incidence and severity were evaluated at the R5.1 (grains perceptible to touch, equivalent to $10 \%$ grain formation), R5.4 (51\% to $75 \%$ grain formation), and R6 (full grain) stages.

Plant height and soybean yield were measured at harvest. Grain yield and 1000-grain weight were measured at $13 \%$ moisture, and values were adjusted to $\mathrm{kg} \cdot \mathrm{ha}^{-1}$. 


\section{RESULTS AND DISCUSSION}

\section{Production of winter cereal straw}

The associations between cultivation sites (Guarapuava and Palmas) and winter cereal production were examined based on plant height and dry weight. Rye presented higher plant height, followed by oat and triticale, in both municipalities (Table 1). A study by Meinerz et al. (2011) evaluating winter cereal development has highlighted rye for its greater height. The best height development was observed in Palmas, possibly due to the most optimum rainfall distribution during the experimental period in this region (data not shown). According to Rodrigues (2011), at the beginning of germination and emergence, plants require high water availability in the soil, which occurred in Palmas. The cumulative rainfall was $98 \mathrm{~mm}$ in Guarapuava and $171 \mathrm{~mm}$ in Palmas, possibly increasing the plants tolerance to bad weather throughout the growth period.

In Guarapuava, oat showed lower fresh and dry weights than triticale and rye; the fresh weight of ryewas respectively $33.52 \%$ and $59.6 \%$ lower than that of triticale and rye (Table 1). Thedry weights of oatwere 7,840 and 15,611 kg $\cdot \mathrm{ha}^{-1}$ in Guarapuava and Palmas, respectively, and these values were higher than those reported by Demétrio et al. (2012) in five oat varieties (common black, IAPAR 61, IPR 126, FAPA, and FUNDACEP FAPA 43) in Santa Helena (average dry weight, 4,290 kg $\mathrm{ha}^{-1}$ ).

The dry weight of oat cultivated in Palmas was almost twice the value in Guarapuava. This may be because of lower temperature (by $1.8^{\circ} \mathrm{C}$ ) in Palmas than in Guarapuava. A low temperature favors the development of winter cereals, since it improve vernalization. Fontaneli et al. (2012) reported that rye showed higher fodder production (fresh weight) during colder periods due to the physiological characteristics of the plant, thus explaining the higher rye fresh weight in Palmas.Meinerz et al. (2011) reported a greater increase in the fresh weight of rye than of oat, barley, and wheat. In our study, rye and triticale showed the highest straw production in the municipality of Guarapuava.

In vitro effects of winter cereal straws on the carpogenic germination of Sclerotinia sclerotiorum

Carpogenic germination was observed only in the control treatment (4 $\mathrm{mm}$ of soil cover on the sclerotia), and apothecia formation was observed at 37,60, and 95 days after the start of the experiment (Table 2). Higher illuminance and aeration on the sclerotia in the absence of straw cover possibly created favorable conditions for apothecia formation, as described by Wu\&Subbarao(2008).

The straw may or may not coverthe soil, interfering with the illuminance necessary for germination. Venturosoet al. (2013) evaluated the effectiveness of various vegetation covers and reported that Brachiaria straw cover was highly effective because of its highdry weight. B. ruziziensis cover inhibited the formation of apothecia in tropical climate regions (GORGENet al., 2009); although, the cultivation of this grass is not feasible in a region with low temperature, which impairs its development.

In treatments with winter cereal straws, the physical barrier formed was unfavorable forthe carpogenic germination of sclerotia (Table 2). Similar results were observed by Silva et al. (2011), who reported that crop residues of oat, bean, vetch, and millet suppressed the carpogenic germination of $S$. sclerotiorum sclerotia.

Effects of winter cereal straws in the management of soybean white mold under field conditions

Evaluation of white mold incidence and severity revealed the associations between different areas and their history of winter cereal cultivation. In

Table 1 - Development of winter cereals in the municipalities of Guarapuava and Palmas, expressed as plant height (H), fresh weight (FW), and dry weight (DW).

\begin{tabular}{|c|c|c|c|c|c|c|}
\hline \multirow[t]{2}{*}{ Treatment } & \multicolumn{2}{|c|}{----------------H (cm)----------------' } & \multicolumn{2}{|c|}{ 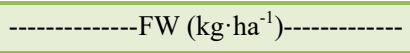 } & \multicolumn{2}{|c|}{----DW $\left(\mathrm{kg} \cdot \mathrm{ha}^{-1}\right)-$} \\
\hline & Guarapuava & Palmas & Guarapuava & Palmas & Guarapuava & Palmas \\
\hline Oat & $91.0 \mathrm{bB}$ & $106.5 \mathrm{bA}$ & $12.474 \mathrm{bB}$ & $19.502 \mathrm{aA}$ & $7.840 \mathrm{bB}$ & $15.611 \mathrm{aA}$ \\
\hline Rye & $120.1 \mathrm{aB}$ & $132.3 \mathrm{aA}$ & $19.925 \mathrm{aA}$ & $20.680 \mathrm{aA}$ & $13.154 \mathrm{aA}$ & $16.028 \mathrm{aA}$ \\
\hline Triticale & $89.6 \mathrm{cA}$ & $92.2 \mathrm{cA}$ & $18.765 \mathrm{aA}$ & $17.640 \mathrm{aA}$ & $12.302 \mathrm{abA}$ & $12.857 \mathrm{aA}$ \\
\hline CV (\%) & \multicolumn{2}{|c|}{7.42} & \multicolumn{2}{|c|}{21.37} & \multicolumn{2}{|c|}{25.89} \\
\hline
\end{tabular}

Different lower- and uppercase letters in columns and rows indicate significant differences (Tukey test, $5 \%$ probability). 
Table 2 - Effects of winter cereal straws on the number of Sclerotinia sclerotiorum apothecia under controlled conditions in days (d) after the start of the experiment.

\begin{tabular}{|c|c|c|c|}
\hline \multirow[t]{2}{*}{ Treatments } & \multicolumn{3}{|c|}{ 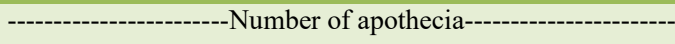 } \\
\hline & $37 \mathrm{~d}$ & $60 \mathrm{~d}$ & $95 \mathrm{~d}$ \\
\hline Soil layer (4 mm) & $10.4 \mathrm{a}^{*}$ & $9.80 \mathrm{a}$ & $9.80 \mathrm{a}$ \\
\hline Triticale produced in Guarapuava $\left(10 \mathrm{t} \cdot \mathrm{ha}^{-1}\right)$ & $0.0 \mathrm{~b}$ & $0.0 \mathrm{~b}$ & $0.0 \mathrm{~b}$ \\
\hline Oat produced in Guarapuava $\left(10 \mathrm{t} \cdot \mathrm{ha}^{-1}\right)$ & $0.0 \mathrm{~b}$ & $0.0 \mathrm{~b}$ & $0.0 \mathrm{~b}$ \\
\hline Rye produced in Guarapuava $\left(10 \mathrm{t} \cdot \mathrm{ha}^{-1}\right)$ & $0.0 \mathrm{~b}$ & $0.0 \mathrm{~b}$ & $0.0 \mathrm{~b}$ \\
\hline Triticale produced in Guarapuava $\left(6.46 \mathrm{t} \cdot \mathrm{ha}^{-1}\right)$ & $0.0 \mathrm{~b}$ & $0.0 \mathrm{~b}$ & $0.0 \mathrm{~b}$ \\
\hline Oat produced in Guarapuava $\left(4.63 \mathrm{t} \cdot \mathrm{ha}^{-1}\right)$ & $0.0 \mathrm{~b}$ & $0.0 \mathrm{~b}$ & $0.0 \mathrm{~b}$ \\
\hline Rye produced in Guarapuava $\left(6.77 \mathrm{t} \cdot \mathrm{ha}^{-1}\right)$ & $0.0 \mathrm{~b}$ & $0.0 \mathrm{~b}$ & $0.0 \mathrm{~b}$ \\
\hline Triticale produced in Palmas $\left(10 \mathrm{t} \cdot \mathrm{ha}^{-1}\right)$ & $0.0 \mathrm{~b}$ & $0.0 \mathrm{~b}$ & $0.0 \mathrm{~b}$ \\
\hline Oat produced in Palmas $\left(10 \mathrm{t} \cdot \mathrm{ha}^{-1}\right)$ & $0.0 \mathrm{~b}$ & $0.0 \mathrm{~b}$ & $0.0 \mathrm{~b}$ \\
\hline Rye produced in Palmas $\left(10 \mathrm{t} \cdot \mathrm{ha}^{-1}\right)$ & $0.0 \mathrm{~b}$ & $0.0 \mathrm{~b}$ & $0.0 \mathrm{~b}$ \\
\hline Triticale produced in Palmas $\left(7.72 \mathrm{t} \cdot \mathrm{ha}^{-1}\right)$ & $0.0 \mathrm{~b}$ & $0.0 \mathrm{~b}$ & $0.0 \mathrm{~b}$ \\
\hline Oat produced in Palmas $\left(5.57 \mathrm{t} \cdot \mathrm{ha}^{-1}\right)$ & $0.0 \mathrm{~b}$ & $0.0 \mathrm{~b}$ & $0.0 \mathrm{~b}$ \\
\hline Rye produced in Palmas $\left(7.33 \mathrm{t} \cdot \mathrm{ha}^{-1}\right)$ & $0.0 \mathrm{~b}$ & $0.0 \mathrm{~b}$ & $0.0 \mathrm{~b}$ \\
\hline $\mathrm{CV}(\%)$ & 26.88 & 18.68 & 27.56 \\
\hline
\end{tabular}

Means followed by the same letter do not differ significantly from each other (Tukey test, 5\% probability).

Guarapuava, soybean cultivated on rye and triticale straws showed a lower white mold incidence at all stages (R5.1, R5.4, and R6).Meanwhile, soybean cultivatedon oat straw showed the same white mold incidence as controls (without straw) (Table 3).

In Palmas, soybean cultivated on any winter cereal straw, specifically rye, showed a lower incidence of white mold than controlsatthe R5.1 and R5.4 stages (Table 4). The best performance of oat straw in controlling white mold in Palmas can be attributed to its greater straw yield in this region $\left(15,611 \mathrm{~kg} \cdot \mathrm{ha}^{-1}\right)$ than in Guarapuava $\left(7,840 \mathrm{~kg} \cdot \mathrm{ha}^{-1}\right)$.

The type of straw can influence disease incidence. Venturoso et al. (2013) evaluated the effectiveness of Brachiaria and sunflower cover and reported that their use delayed the carpogenic germination of sclerotia by acting as a physical barrier and decreasing luminance.

In Palmas, compared with the control treatment (no straw), rye straw decreased white mold incidence by $92.3 \%, 88.4 \%$, and $77.6 \%$ at the R5.1, R5.4, and R6 stages, respectively (Table 3). Successful sclerotia germination increases white mold incidence. The physical barrier provided by straw reduced illuminance, which may have affected carpogenic germination. In a study comparing sclerotia germination in the presence and absence of B. ruziziensis cover, Gorgen et al. (2009) reported a $98 \%$ reduction in the number of apothecia formed with the use of vegetation cover.

Table 3 - Incidence of white mold (\%) on soybean at different phenological stages (R5.1, R5.4, and R6) when cultivated in soil covered with oat, rye, and triticale straws or in soil without cover in Guarapuava and Palmas.

\begin{tabular}{lcccccc}
\hline Treatments & Guarapuava & Palmas & Guarapuava & Palmas & Guarapuava \\
\hline No cover & $1.4 \mathrm{bA}^{*}$ & $1.2 \mathrm{bA}$ & $13.0 \mathrm{bA}$ & $15.0 \mathrm{bA}$ & $15.3 \mathrm{bA}$ & $23.5 \mathrm{cB}$ \\
Oat & $1.2 \mathrm{bB}$ & $0.3 \mathrm{aA}$ & $10.2 \mathrm{bA}$ & $7.3 \mathrm{abA}$ & $13.8 \mathrm{bA}$ & $13.1 \mathrm{bA}$ \\
Rye & $0.2 \mathrm{aA}$ & $0.1 \mathrm{aA}$ & $1.9 \mathrm{aA}$ & $1.7 \mathrm{aA}$ & $3.6 \mathrm{aA}$ & $5.2 \mathrm{aA}$ \\
Triticale & $0.2 \mathrm{aA}$ & $0.2 \mathrm{aA}$ & $2.5 \mathrm{aA}$ & $8.2 \mathrm{aA}$ & $4.8 \mathrm{aA}$ \\
$\mathrm{CV}(\%)$ & & & & 18.87 & & \\
\hline
\end{tabular}

Different lower- and uppercase letters in columns and rows indicate significant differences (Tukey test, $5 \%$ probability). 
Table 4 - Severity of white mold (\%) on soybean at different phenological stages (R5.1, R5.4, and R6) when cultivated in soil covered with oat, rye, and triticale straws or in soil without cover in Guarapuava and Palmas.

\begin{tabular}{|c|c|c|c|c|c|c|}
\hline Treatment & \multicolumn{2}{|c|}{-----------------R5.1----------------' } & \multicolumn{2}{|c|}{-------------------R5.4------------------- } & \multicolumn{2}{|c|}{----------------------R6-------------------- } \\
\hline & Guarapuava & Palmas & Guarapuava & Palmas & Guarapuava & Palmas \\
\hline No cover & $32.3 \mathrm{bA}$ & $28.0 \mathrm{bA}$ & $89.4 \mathrm{bA}$ & $74.6 \mathrm{bA}$ & $90.5 \mathrm{bA}$ & $85.2 \mathrm{cA}$ \\
\hline Oat & $16.4 \mathrm{aA}$ & $15.3 \mathrm{aA}$ & $64.0 \mathrm{abA}$ & $54.5 \mathrm{abA}$ & $78.9 \mathrm{abB}$ & $64.0 \mathrm{abA}$ \\
\hline Rye & $27.0 \mathrm{bB}$ & $16.4 \mathrm{aA}$ & $82.0 \mathrm{abA}$ & $58.7 \mathrm{abA}$ & $88.4 \mathrm{abB}$ & $69.3 \mathrm{bA}$ \\
\hline Triticale & $16.4 \mathrm{aA}$ & $13.2 \mathrm{aA}$ & $52.4 \mathrm{aA}$ & $40.7 \mathrm{aA}$ & $74.6 \mathrm{aB}$ & $54.5 \mathrm{aA}$ \\
\hline CV $(\%)$ & \multicolumn{2}{|c|}{23.06} & \multicolumn{2}{|c|}{16.48} & \multicolumn{2}{|c|}{21.43} \\
\hline
\end{tabular}

Different lower- and uppercase letters in columns and rows indicate significant differences (Tukey test, $5 \%$ probability).

In Guarapuava and Palmas,white mold severity was reduced by respectively $2.3 \%$ and $18.6 \%$ using rye straw and by respectively $17.2 \%$ and $36.2 \%$ using triticale straw. In the absence of straw (control), disease severity was the highest (Table 4). Although,the use of straws reduced disease severity, it differed between the two study sites.

In Palmas, disease severity was the highest in the absence of cover at the R6 stage. In this area, soybean cultivated on winter cereal straws showed $60 \%$ lower disease severity than soybean cultivated without straw. In Guarapuava, disease severity was reduced by $76.5 \%$ and $68.7 \%$ using rye and triticale straws, respectively. Pereira \&Blum (2010) have reported similar decreases in the incidence of other diseases, such as neck rot in common bean (Sclerotium rolfsii) cultivated on millet straw.

Another explanation of variations in disease severity across different sites may be the history of cultivation. In Palmas, forage turnip was previously used as cover. According to Brustolin et al. (2012), forage turnip is one of the hosts of white mold, and the presence of moisture due to rain or mist is an important factor for sclerotia germination. These factors may affect the incidence and severity of white mold. According to Wu \& Subbarao (2008), soil moisture is an important factor for sclerotium germination and apothecium development.

There weresignificant differencesin plant height, 1000-grain weight, and grain yield between the two study sites, indicating regional effects on crop development. However, there were no associations between sites and individual treatment effects (Table 5).

In the absence of straw, plant height in Guarapuava was approximately $60 \%$ higher than that in Palmas, possibly due to the effects of temperature and high altitude on crop development. The 1000-grain weightwas different between the two study sites, being higher in Palmas across all treatments (Table 5). This variation can be explained by different temperatures in the two regions. Palmas showed lower mean temperatures in December and January $\left(2.13{ }^{\circ} \mathrm{C}\right.$ and $1.16{ }^{\circ} \mathrm{C}$, respectively) than Guarapuava, thus providing optimum conditions to achieve better physiological seed quality, which may

Table 5 - Plant height, 1000-grain weight, and crop yield of soybean grown in soil covered with different straws in Guarapuava and Palmas.

\begin{tabular}{|c|c|c|c|c|c|c|}
\hline \multirow{2}{*}{ Treatments } & \multicolumn{2}{|c|}{----------Plant height $(\mathrm{cm})$---------- } & \multicolumn{2}{|c|}{--------1000-grain weight(g)------- } & \multicolumn{2}{|c|}{--------Productivity $\left(\mathrm{kg} \mathrm{ha}^{-1}\right)$------- } \\
\hline & Guarapuava & Palmas & Guarapuava & Palmas & Guarapuava & Palmas \\
\hline No cover & $93.4 \mathrm{~A}^{*}$ & $58.7 \mathrm{~B}$ & $156.7 \mathrm{~B}$ & $195.4 \mathrm{~A}$ & $3.2 \mathrm{~A}$ & $3.4 \mathrm{~A}$ \\
\hline Oat & $94.6 \mathrm{~A}$ & $60.9 \mathrm{~B}$ & $162.1 \mathrm{~B}$ & $192.1 \mathrm{~A}$ & $3.3 \mathrm{~A}$ & $3.7 \mathrm{~A}$ \\
\hline Rye & $95.7 \mathrm{~A}$ & $67.3 \mathrm{~B}$ & $163.9 \mathrm{~B}$ & $194.9 \mathrm{~A}$ & $3.8 \mathrm{~A}$ & $3.9 \mathrm{~A}$ \\
\hline Triticale & $92.6 \mathrm{~A}$ & $64.7 \mathrm{~B}$ & $163.8 \mathrm{~B}$ & $188.1 \mathrm{~A}$ & $3.3 \mathrm{~B}$ & $4.1 \mathrm{~A}$ \\
\hline
\end{tabular}

Different lower- and uppercase letters in columns and rows indicate significant differences (Tukey test, 5\% probability).

*There were no significant differences among treatments at the same cultivation site. 
have reflected in grain weight in this region.Nunes et al. (2010) reported nodifferences in 1000-grain weightand yield between areas with soybean cultivation on $B$. decumbens and $B$. brizantha straws.

\section{CONCLUSION}

The vegetative development of winter cereals, such as oat, rye, and triticale, was affected by cultivation site (Guarapuava or Palmas). Under the experimental conditions, rye producedt he highest dry weight. Under controlled conditions, winter cereal straws inhibited S. sclerotiorum apothecia formation.

Furthermore, soybean cultivated on rye, triticale, and oat straws showed a lower severity of white mold than soybean cultivated without vegetation cover. The use of rye and triticale straws reduced the incidence of soybean white mold in Guarapuava and Palma.

\section{ACKNOWLEDGEMENTS}

We thank Universidade Estadual do Centro Oeste (UNICENTRO) for providing the physical support for the study, and the Coordenação de Aperfeiçoamento de Pessoal de Nível Superior (CAPES) for financial support (001), for grating the research productivity scholarship to Cacilda Marcia Duarte Rios Faria (Process 310966/2018-3)Conselho Nacional de Desenvolvimento Científico e Tecnológico (CNPq) e a Fundação Araucária

\section{DECLARATION OF CONFLICTS OF INTERESTS}

The authors declare no conflict of interest. The founding sponsors had no role in the design of the study; in the collection, analyses, or interpretation of data; in the writing of the manuscript, and in the decision to publish the results.

\section{AUTHORS' CONTRIBUTIONS}

All authors contributed equally for the conception and writing of the manuscript. All authors critically revised the manuscript and approved of the final version.

\section{REFERENCES}

BRUSTOLIN, R.; et al. Mofo Branco. In: REIS, E.M.; CASA, R.T. (Orgs.) Doenças da soja.Passo Fundo: Berthier, 2012. p. 217-232.

CUNHA, M.C.; OLIVEIRA, E.D.; THOMAZ, E.L.; VESTENA, L.R. Análise Temporal do Balanço Hídrico na Bacia do Rio das Pedras, Guarapuava, PR. Revista Brasileira de Geografia Física, Recife, v.5, p.1013-1028, 2011. Available from: <https:// periodicos.ufpe.br/revistas/rbgfe/article/view/232752>. Accessed: Apr. 15, 2019. doi: 10.26848/rbgf.v4.5.p1013-1028.

DEMÉTRIO, J.V.; COSTA, A.C.T.; OLIVEIRA, P.S.R. Produção de biomassa de cultivares de aveia sob diferentes manejos de corte. Pesquisa Agropecuária Tropical, Goiânia, v.42, n.2, p.198-205,
2012.Available from: <https://www.revistas.ufg.br/pat/article/ view/16217>. Accessed: Jan. 20, 2019. doi: 10.1590/S198340632012000200011

GORGEN, C.A.; CIVARDI, E.A.; RAGAGNIN, V.A.; SILVEIRA NETO, A.N.; CARNEIRO, L.C.; LOBO JUNIOR, M. Redução do inóculo inicial de Sclerotinia sclerotiorum em soja cultivada após uso do sistema Santa Fé. Pesquisa Agropecuária Brasileira, Brasília, v.45, n.10, p.1102-1108, 2010. Available from: $<$ https://doi.org/10.1590/S0100-204X2010001000008>. Accessed: Jan. 15, 2019. doi: 10.1590/S0100-204X2010001000008.

GORGEN, C.A.; SILVEIRA NETO, A.N. da; CARNEIRO, L.C.; RAGAGNIN, V.A.; LOBO JUNIOR, M. Controle do mofobranco com palhada e Trichoderma harzianum $1306 \mathrm{em}$ soja. Pesquisa Agropecuária Brasileira, Brasília, v.44, p.1583-1590, 2009. Available from: <https://www.scielo.br/pdf/pab/v44n12/ v44n12a04.pdf>. Accessed: Feb. 11, 2019. doi: 10.1590/S0100204X2009001200004.

GUARESCHI, R.F.; PERIN, A.; MACAGNAN, D.; TRAMONTINI, A.; GAZOLLA, P.R. Emprego de Trichoderma spp. no controle de Sclerotiniasclerotiorum e na promoção de crescimento vegetativo nas culturas de girassol e soja. Global Science And Technology, v.05, n.02, p.01-08, 2012. Available from: <https://rv.ifgoiano.edu.br/periodicos/index.php/gst/article/ view/148/293\#>. Accessed: Apr. 24, 2019.

HANSENA, Z.R.; KEINATH, A.P. Increased pepper yields following incorporation of biofumigation cover crops and the effects on soilborne pathogen populations and pepper diseases. Applied Soil Ecology, v.63, p.67-77, 2013. Available from: <https://doi.org/10.1016/j.apsoil.2012.09.007>. Accessed: Feb. 12, 2019. doi: 10.1016/j.apsoil.2012.09.007.

JULIATTI, F. C., DO CRATO, F. F., JULIATTI, F. C., COUTO, K., \& JULIATTI, B. C. M. Escala diagramática para avaliação da severidade de mofo branco em soja. Bioscience Journal, v.29, n.3, p.676-680, 2013.Available from: <http://www.seer.ufu.br/index.php/ biosciencejournal/article/view/22440>. Accessed: Feb. 20, 2019.

MEINERZ, G.R.; CLAIR, C.J.; VIÉGAS, J.; NÖRNBERG, J.L.; AGNOLIN, C.A.; SCHEIBLER, R.B.; HORST, T.; FONTANELI, R.S. Silagem de cereais de inverno submetidos ao manejo de duplo propósito. Revista Brasileira de Zootecnia, v.40, n.10, p.20972104, 2011. Available from: <https://doi.org/10.1590/S151635982011001000005>. Accessed: Feb. 20, 2019. doi: 10.1590/ S1516-35982011001000005.

MUNDSTOCK, C. M. Cultivo dos cereais de estação fria: trigo, cevada, aveia, centeio, alpiste, triticale. Porto Alegre: NBS, 1983. 265p.

NUNES, A.S.; TIMOSSI, P.C.; PAVANI, M. C.M.O.D.; COSTA ALVES, A.P.L. Straw Cover Formation and Weed Management in Soybean under No-Tillage System. Planta Daninha, Viçosa, v.28, n.4, p.727-733, 2010. Available from: <https://doi.org/10.1590/ S0100-83582010000400004>. Accessed: Feb. 15, 2019. doi: $10.1590 / \mathrm{S} 0100-83582010000400004$.

PEREIRA NETO, J.V.P.; BLUM, L.E.B. Adição de palha de milheto ao solo para redução da podridão do colo em feijoeiro. Pesquisa Agropecuária Tropical, Goiânia, v.40, n.3, p.354-361, 2010. Available from: <https://www.revistas.ufg.br/index.php/pat/ article/view/6417>. Accessed: Feb. 13, 2019. doi: 10.5216 / pat. v40i3.6417. 
RODRIGUES, O. Trigo no Brasil. Passo Fundo: Embrapa Trigo, 2011 p.115-131.

SILVA, F.P.M.; GAVASSONI, W.L.; BACCHI, L.M.A; GARCEZ, F.R.Germinação carpogênica de Sclerotinia sclerotiorum sob diferentes resíduos e extratos de plantas cultivadas.Summa Phytopathologica, Botucatu, v.37, n.3, p.131-136, 2011. Available from: <https://doi.org/10.1590/S01005405201100030009>. Accessed: Mar. 03, 2019. doi: 10.1590/ S0100-54052011000300009.

TUPICH, F. L. B., FANTIN, L. H., DA SILVA, A. L., \& CANTERI, M. G. Impacto do controle do mofo-branco com fluazinam na produtividade da soja no Sul do Paraná: metanálise. Summa Phytopatholica, v.43, n.2, p.145-150, 2017. Avaliable from: $<$ https://doi.org/10.1590/0100-5405/168479>. Accessed: Fev. 23, 2019. doi: 10.1590/0100-5405/168479.
VENTUROSO, L.R.; BACCHI, L.M.A.; GAVASSONI, W.L.; VENTUROSO, L.A.G.; ESPINDOLA, D.L.P.; DOS SANTOS, J.A.E. Produção de soja e germinação carpogênica de Sclerotinia sclerotiorum sob diferentes coberturas de solo. Semina: Ciências Agrárias, Londrina, v.34, n.2, p.615626, 2013.Available from: <https://pdfs.semanticscholar. org/d736/21 cdd0507fd3f74a52c82d869bda6aada86d.pdf>. Accessed: Mar. 14, 2019. doi: 10.5433/1679-0359.2013v34 $\mathrm{n} 2 \mathrm{p} 615$.

WU, B. M.; SUBBARAO, K. V. Effects of soil temperature, moisture, and burial depths on carpogenic germination of Sclerotinia sclerotiorum and S. minor. Phytopathology, Saint Paul, v.98, n.10, p.1144-1152, 2008. Available from: <https://doi. org/10.1094/PHYTO-98-10-1144>. Accessed: Abr. 21, 2019. doi: 0.1094/PHYTO-98-10-1144. 